\title{
IDA BUDHIATI : PERJUANGAN PEREMPUAN KE PARLEMEN
}

\author{
Fajar Setiawan \\ Aktivis Hak Asasi Manusia \\ Email : fajarfajar93@gmail.com
}

\begin{abstract}
ABSTRAK
Pengaturan kuota perempuan diparlemen mempunyai sejarah Panjang, dengan kata lain banyak dinamika mengenai perkembangan kuota perempuan untuk masuk ke parlemen dari rezim orde baru sampai dengan pasca reformasi mempunyai perbedaan pengaturan terkait dengan pengaturan yang mendorong perempuan masuk ke parlemen. Perempuan didorong untuk masuk ke parlemen melalui jalur pemilihan dimana penyelenggara pemilu memberikan syarat khsusu bagi peserta pemilu dalam memilih calon legislatifnya harus memenuhin kuota perempuan.
\end{abstract}

Keyword : perempuan, kuota, parlemen

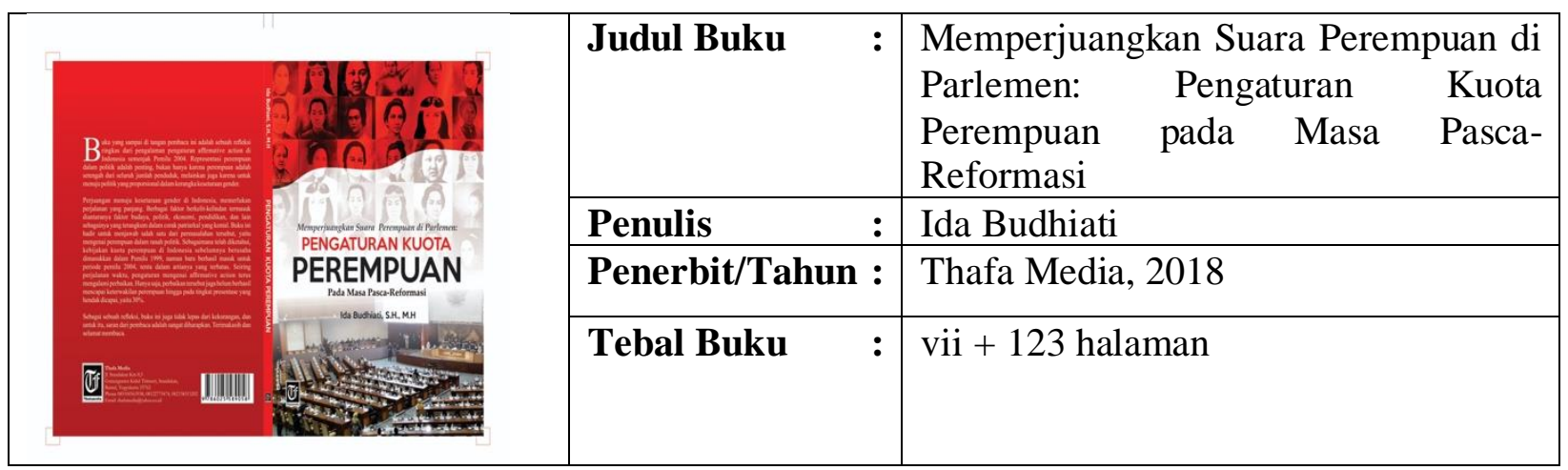

Buku ini menyoroti sejarah perkembangan kebijakan pengaturan kuota di Indonesia untuk meningkatkan representasi suara perempuan di parlemen. Pengaturan kuota adalah bentuk konkret dari affirmative action, yakni perlakuan khusus sementara yang ditujukan untuk mengangkat status suatu kaum yang dirugikan dari bentuk-bentuk diskriminasi. Dalam konteks representasi politik perempuan, Affirmative action hadir sebagai sarana untuk mengintervensi konstruksi diskriminatif yang menahun di setiap stakeholder dan pemain politik yang menghambat perempuan Indonesia untuk menyampaikan, memperjuangkan, dan merealisasikan hak asasinya sebagai warga negara yang diperlakukan setara terhadap laki-laki.

Dalam buku berisikan 7 bab ini, Penulis mengajak pembaca untuk mengarungi dinamika perkembangan pengaturan kuota di Indonesia, tentunya dengan asumsi awal bahwa penerapan kuota perempuan sangat penting dalam mewujudkan kesetaraan gender di institusi politik seperti parlemen. Pada awalnya, asumsi ini dapat memberikan kesan pola narasi yang datar, naïf, dan hanya dari satu perspektif. Nyatanya, Penulis hanya memberikan analisa teoritis dan normatif hukum affirmative action di dalam bab pertama. Sebagian besar isi buku justru berfokus pada pemaparan analisa empiris dalam konteks sosial-politik yang tidak hanya mempengaruhi dinamika pengaturan kuota perempuan di era pasca-reformasi, namun pula faktor-faktor yang 
melatarbelakangi pengaturan kuota sebagaimana dijelaskan dalam Bab 2 mengenai gerakan perempuan di era Orde Lama yang berumur pendek karena diporakporandakan tragedi 30 September dan represi gerakan perempuan di rezim Orde Baru.

Pada konteks pasca-reformasi, buku ini memaparkan secara detail dalam bab 3, 4, dan 5 mengenai perubahan-perubahan pengaturan kuota dalam hukum terhitung dari periode pemilu 2004, dimana kuota pertama kali diimplementasikan, hingga 2014. Di buku ini, Penulis membagi perkembangan pengaturan kuota perempuan di masa pasca-reformasi menjadi tiga periode, sesuai dengan 3 periode pemilu, periode pemilu 2004, 2009, dan 2014. Di Bab 3, Penulis mengilustrasikan implementasi affirmative action pertama kali di periode 2004 dengan kata-kata kunci seperti "setengah hati" dan "persiapan. Kata kunci ini merefleksikan situasi politik, sosial, dan budaya yang mengakibatkan lemahnya legitimasi hukum affirmative action, yang pada saat itu hanya dicantumkan dalam pasal 65 ayat 1 UU 12/2003 tentang Pemilu dan UU 31/2002 tentang Partai Politik yang hanya mengandalkan good will partai politik untuk mengajukan calon perempuan tanpa ada perintah yang kuat. Konsekuensi dari pemilu 2004 adalah refleksi dan perbaikan di periode berikutnya, pemilu 2008, yang dibahas di bab 4. Isu utama di dalam topk refleksi dan perbaikan pengaturan kuota di periode ini adalah penguatan legitimasi hukum dan ketegasannya untuk "memaksa" partai politik menerapkan kuota partisipasi perempuan dalam keanggotaan dan nominasi caleg, yang terbukti ampuh dikarenakan formulasi hukum yang ketat dan tegas di kebijakan pemilu yang baru. Pasca pemilu 2008, isu representasi perempuan dan sistem kuota beralih focus, sebagaimana dijelaskan di bab 5. Disinilah momen dimana kesadaran stakeholder, actor politik, dan masyarakat dalam memajukan kesetaraan gender belum dapat tercapai bila hanya melalui sistem kuota yang terlalu kuantitatif dan tidak berdampak pada pembentukan perilaku yang lebih sadar gender.

Pemaparan historis di atas merefleksikan pemikiran sang penulis dalam bagaimana merumuskan desain pengaturan kuota yang ideal dalam meningkatkan representasi perempuan di parlemen Indonesia. Di bab 6 dan 7, penulis menjelaskan keuntungan dan kerugian dari berbagai desain pemilu yang telah diimplementasikan di Indonesia, dari sistem proporsional tertutup semasa Orde Baru dan sistem proporsional terbuka pada masa pasca-Reformasi. Disini penulis menyimpulkan bahwa tiap desain memiliki dampak positifnya sendiri terhadap gerakan perempuan dan representasi perempuan di politik. Di satu sisi, sistem proporsional tertutup yang dikontrol rezim otoriter Orde Baru justru menimbulkan anomali positif di gerakan perempuan yang menjadi lebih kritis dan ulet dalam memperjuangkan agendanya yang pada hasilnya adalah agen-agen representasi perempuan yang benar-benar mampu secara kapabilitas intelektual maupun politik. Orde Baru nyatanya telah menciptakan figure-figur feminis Indonesia yang kita kenal sekarang. Namun di sisi lain, penulis menunjukkan bahwa budaya politik di era yang lebih demokratis pascareformasi malah mengaburkan kualitas substantif dari agensi gerakan perempuan menjadi sekedar pemenuhan syarat $30 \%$ keanggotaan perempuan di partai politik. Terbelum lagi permasalahan payung hukum yang seringkali kontradiktif dan tidak menurun secara linear ke peraturan-peraturan yang lebih rendah, serta minimnya perlindungan otoritas terhadap Komisi Pemilihan Umum.

Secara keseluruhan, impresi saya adalah buku ini berupaya untuk menyajikan secara ringkas data dan fakta historis mengenai implementasi pengaturan kuota perempuan di Indonesia, yang tentunya tidak sempurna dan tidak selalu asertif secara hukum, sembari "mewariskan" tugas kepada pembaca untuk berkontemplasi mengenai desain affirmative action yang tepat untuk 
pemilu mendatang, terutama pemilu 2019. Untungnya, penulis tidak bersikap egois, melainkan membantu pembaca untuk memahami, kemudian merefleksikan, permasalahan pemilu dan gender di Indonesia dengan memberikan petunjuk di sana-sini mengenai apa-apa yang perlu untuk dirubah, dipertahankan, atau bahkan dihilangkan. Namun, inti refleksi yang sang penulis berupaya ekspresikan di sepanjang buku adalah pentingnya reformasi holistik untuk mencapai kesetaraan gender di politik, tidak hanya melalui kebijakan kuota dalam hukum pemilu, namun pula dengan agenda-agenda di aspek lain seperti sosial, budaya, dan politik. 